\title{
Loss of zinc transporters ZIP1 and ZIP3 augments platelet reactivity in response to $G$ protein-coupled receptor agonists and accelerates thrombus formation in vivo
}

\author{
Elgheznawy $A,{ }^{1}$ Öftering $P,{ }^{2}$ Englert $M,{ }^{2}$ Kaiser $F,{ }^{3}$ Kusch $C,{ }^{2}$ Gbureck $U,{ }^{3}$ Bösl $M R,{ }^{2}$ \\ Nieswandt $B,{ }^{2}$ Vögtle $\mathrm{T}^{2}{ }^{2}$ Hermanns $\mathrm{HM}^{1 *}$
}

\begin{abstract}
${ }^{1}$ Medical Clinic II, Division of Hepatology, University Hospital Würzburg, 97080 Würzburg, Germany ${ }^{2}$ Institute of Experimental Biomedicine I, University Hospital and Rudolf Virchow Center for Integrative and Translational Bioimaging, University of Würzburg, 97080 Würzburg, Germany

${ }^{3}$ Department for Functional Materials in Medicine and Dentistry, University Hospital Würzburg, 97070 Würzburg, Germany.
\end{abstract}

*Corresponding author (Hermanns_H@ukw.de)

\begin{abstract}
Zinc $\left(\mathrm{Zn}^{2+}\right)$ is considered as an important mediator for thrombosis and haemostasis. However, our understanding of the transport mechanisms that regulate $\mathrm{Zn}^{2+}$ homeostasis in platelets is limited. $\mathrm{Zn}^{2+}$ transporters, ZIPs and ZnTs, are widely expressed in eukaryotic cells. Using mice globally lacking ZIP1 and ZIP3 (ZIP1/3 DKO), our aim was to explore the potential role of these well-known $\mathrm{Zn}^{2+}$ transporters in maintaining platelet $\mathrm{Zn}^{2+}$ homeostasis and in the regulation of platelet function. While ICP-MS measurements indicated unaltered overall $\mathrm{Zn}^{2+}$ concentrations in platelets of ZIP1/3 DKO mice, we observed a significantly delayed and less efficient $\mathrm{Zn}^{2+}$ release upon thrombin-stimulated platelet activation. This resulted in a hyperactive platelet response not only in response to thrombin, but also towards other $\mathrm{G}$ protein-coupled receptor (GPCR) agonists. Immunoreceptor tyrosine-based activation (ITAM)-coupled receptor agonist signalling, however, was unaffected. Augmented GPCR responses were accompanied by enhanced $\mathrm{Ca}^{2+}$ signalling and PKC activation. Further functional analysis of ZIP1/3 double deficient mice revealed enhanced platelet aggregation, bigger thrombus volume under flow ex vivo and faster in vivo thrombus formation. The current study thereby identifies ZIP1 and ZIP3 as important regulators for the maintenance of platelet $\mathrm{Zn}^{2+}$ homeostasis and function.
\end{abstract}

\section{Introduction}

Zinc $\left(\mathrm{Zn}^{2+}\right)$ is an essential micronutrient that represents the second most abundant transition element in the body next to iron (1,2). In the human body, plasma contains $0.1 \%$ of total $\mathrm{Zn}^{2+}$, while the majority of $\mathrm{Zn}^{2+}$ content is present intracellularly $(3,4)$. Cellular $\mathrm{Zn}^{2+}$ exists either tightly or loosely protein-bound or in a free or non-proteinous ligand-bound status referred to as mobile or labile zinc (3). $\mathrm{Zn}^{2+}$ binds to nearly $10 \%$ of human proteins to act as a cofactor for maintaining normal cellular signalling $(2,5,6)$. 
$\mathrm{Zn}^{2+}$ is enriched in platelets and is primarily stored in their a-granules or bound to metallothionein in the cytosol at concentrations up to 30- to 60-fold higher than in the plasma (7-9). Upon platelet activation, $\mathrm{Zn}^{2+}$ is released into the circulation and in the microenvironment of the growing thrombus to modulate the activity of several proteins that are involved in platelet aggregation, coagulation and fibrin clot formation (10-13). Consistent with that, blood serum has higher $\mathrm{Zn}^{2+}$ concentrations than plasma, indicating that activated platelets release stored $\mathrm{Zn}^{2+}$ during clot formation (14). Furthermore, $\mathrm{Zn}^{2+}$ deficiency can result in impaired platelet activity and increased bleeding times $(15,16)$. Therefore, $\mathrm{Zn}^{2+}$ acts as an important mediator of haemostasis and thrombosis (10,17-19).

Studies in recent years have suggested that functions of exogenous $\mathrm{Zn}^{2+}$ are distinct depending on the concentration. For instance, at low concentrations $(30 \mu \mathrm{M})$, exogenous $Z^{2+}$ works as a coactivator via potentiating platelet responses to GPCR and ITAM-coupled receptor agonists to promote platelet activation $(20,21)$. Consistent with that, increased nutritional $\mathrm{Zn}^{2+}$ intake increases platelet reactivity in response to suboptimal doses of thrombin, ADP, collagen and adrenaline (22). At intermediate concentrations (0.1-1 mM), exogenous $\mathrm{Zn}^{2+}$ can act as platelet agonist to regulate intracellular signalling, leading to granule secretion and $\mathrm{PKC} / \mathrm{\alpha}_{\| \mathrm{b}} \beta_{3}$-dependent aggregation $(20,21,23)$. On the contrary, at high concentrations ( $3 \mathrm{mM}$ ), extracellular $\mathrm{Zn}^{2+}$ impaired platelet aggregation, indicating that $\mathrm{Zn}^{2+}$ homeostasis needs to be tightly regulated in platelets as uncontrolled increase of labile $\mathrm{Zn}^{2+}$ above physiological limits may lead to cell toxicity $(17,24)$. These observations indicate the existence of $\mathrm{Zn}^{2+}$ uptake, storage, and release mechanisms to control $\mathrm{Zn}^{2+}$ homeostasis in platelets.

$\mathrm{Zn}^{2+}$ cannot permeate through the phospholipid bilayers. Therefore, it requires a regulatory machinery to actively control the transport and availability of $\mathrm{Zn}^{2+}$ in the cytoplasm, different intracellular organelles, and extracellular space $(17,25)$. $\mathrm{Zn}^{2+}$ transporting proteins and a $\mathrm{Zn}^{2+}$ buffer system are the main mechanisms to maintain $\mathrm{Zn}^{2+}$ homeostasis. $\mathrm{Zn}^{2+}$ transporting proteins involve several non-selective cation channels, exchanger and transporters to regulate $\mathrm{Zn}^{2+}$ permeability across the cell membrane. Of these channels, transient receptor potential channels (TRPC6 and TRPM7) are considered to be $\mathrm{Zn}^{2+}$ permeable $(26,27)$. In addition, the $\mathrm{Na}^{2+} / \mathrm{Ca}^{2+}$ exchanger (NCX) is reported to facilitate $\mathrm{Zn}^{2+}$ movement (28). Although TRP channels and NCX are expressed in platelets and megakaryocytes (MKs) $(29,30)$, nothing is known about their role in the regulation $\mathrm{Zn}^{2+}$ homeostasis in platelets. Besides these rather unspecific channels and exchanger, $\mathrm{Zn}^{2+}$ homeostasis is more specifically regulated by members of Slc30a (zinc transporters; ZnTs) and Slc39a (Zrt-Irt like proteins; ZIPs) gene families $(31,32)$. ZIP members act as importers to mediate $Z \mathrm{Z}^{2+}$ influx into the cytosol thereby increasing cytoplasmic $\mathrm{Zn}^{2+}$ levels, while $\mathrm{ZnT}$ isoforms work as exporters to control $\mathrm{Zn}^{2+}$ efflux thereby reducing cytosolic $\mathrm{Zn}^{2+}$ levels (33). Transcripts of several ZIP members are detected in substantial amounts in MKs such as ZIP1, ZIP3, ZIP4, ZIP6, ZIP7, ZIP9 and ZIP10 (7). In addition, different isoforms of $Z n T s$ are expressed in MKs and platelets such as $Z n T 1, Z n T 5$, $\mathrm{ZnT6}$, ZnT7 and ZnT9 (7,34). Besides $\mathrm{Zn}^{2+}$ transportation, also $\mathrm{Zn}^{2+}$ storage and buffering system are important for the regulation of $Z n^{2+}$ bioavailability and accumulation in response to the intracellular metabolic alterations. The best characterized stores for free labile $\mathrm{Zn}^{2+}$ are the endoplasmic reticulum, Golgi apparatus, vesicles and secretory granules $(9,35)$. However, free mobile $\mathrm{Zn}^{2+}$ is sequestered by the increased amount of high affinity $\mathrm{Zn}^{2+}$-binding proteins that exist in cytosol and nucleus. Here proteins of the metallothionein family are of particular 
relevance which can bind up to seven $\mathrm{Zn}^{2+}$ atoms and release them most likely due to alterations in the redox status (36). The mechanism by which intracellular $\mathrm{Zn}^{2+}$ homeostasis is maintained in terms of platelet activation is unrevealed. Given that $\mathrm{Zn}^{2+}$ transporters are the main regulators for $\mathrm{Zn}^{2+}$ uptake, storage and release to sustain $\mathrm{Zn}^{2+}$ homeostasis, we were interested to explore the role of two plasma membrane localized $\mathrm{Zn}^{2+}$ transporters, ZIP1 and ZIP3, in platelets.

\section{Materials and methods}

\section{Experimental Animals}

Double ZIP1/ZIP3 knockout mice (Slc39a1tm1.1Gka,Slc39a3tm1.1Gka/Mmmh) were originally described by Dufner-Beattie et al. (37). Cryopreserved spermatozoa were obtained from MMRRC, University of Missouri (RRID: MMRRC_015979-MU), and rederived by in-vitrofertilization using C57BL/6J isogenic strain background as oocyte donor according to Takeo, T. et Nakagata, N. (38). Heterozygous mice were crossed to obtain wild-type and DKO litters which were further bred as homozygous lines. For experiments, mice from the same generations were used. Sex-matched and age-matched male and/or female mice were used for all experiments. Experiments were conducted according to the German animal protection law and in accordance with good animal practice as defined by the Federation of Laboratory Animal Science Associations (FELASA) and the national animal welfare body GV-SOLAS. Animal studies were approved by the district government of Lower Franconia (Bezirksregierung Unterfranken).

\section{In vitro differentiation of bone-marrow megakaryocytes}

In vitro differentiation of MKs was carried out as described recently (39) using an antibody mixture in combination with magnetic beads for lineage depletion. The antibody negative fraction was cultured in DMEM (Gibco) containing $50 \mathrm{ng} / \mathrm{ml}$ TPO and $100 \mathrm{U} / \mathrm{ml}$ rHirudin for $72 \mathrm{~h}$, before the cells were enriched by straining them with a $20 \mu \mathrm{m}$ cell strainer prior to experiments.

\section{RNA isolation and quantitative RT-PCR}

Total RNA was isolated from murine MKs using the NucleoSpin RNA kit (Macherey \& Nagel) according to the manufacturer's instructions including a genomic DNA digest. Reverse transcription up to $1 \mu \mathrm{g}$ of RNA was carried out with the High-Capacity cDNA Reverse Transcription Kit (Life Technologies). Quantitative PCR (qPCR) was performed with SYBR Select Master Mix on a ViiA7 (Life Technologies). Gene expression was calculated by the comparative $\Delta \Delta$ Ct-method and normalized to the housekeeping gene Rplp0. All primers had melting temperatures of $58-60^{\circ} \mathrm{C}$ (Primer Express 3.0, Life Technologies).

\section{Platelet preparation}

Murine blood was collected from the retroorbital plexus into $1.5 \mathrm{ml}$ reaction tube containing $300 \mu \mathrm{l}$ heparin in TBS $(20 \mathrm{U} / \mathrm{ml}, \mathrm{pH}$ 7.3). To prepare platelet-rich plasma (PRP), $200 \mu \mathrm{l}$ TBS/heparin were added and blood was centrifuged at $800 \mathrm{rpm}$ for $6 \mathrm{~min}$ at RT. Then, supernatant and buffy coat were transferred into a new tube containing $300 \mu \mathrm{l}$ TBS/heparin and centrifuged at $800 \mathrm{rpm}$ for $6 \mathrm{~min}$ at RT. To prepare washed platelets, PRP was centrifuged 
at $2800 \mathrm{rpm}$ for $5 \mathrm{~min}$ at RT. Platelet pellet was gently resuspended in $1 \mathrm{ml} \mathrm{Ca}^{2+}$-free Tyrode's buffer containing $\mathrm{PGI}_{2}(0.1 \mu \mathrm{g} / \mathrm{ml})$ and apyrase $(0.02 \mathrm{U} / \mathrm{ml})$ and centrifuged at $2800 \mathrm{rpm}$ for 5 min at RT. Finally, the platelet pellet was resuspended in the appropriate volume of $\mathrm{Ca}^{2+}$-free Tyrode's buffer containing apyrase $(0.02 \mathrm{U} / \mathrm{ml})$ to reach the required platelet concentration for experiments.

\section{Measurements of platelet cation levels using ICP-MS}

Washed platelets $\left(1 \times 10^{6} \mathrm{cells} / \mu \mathrm{l}\right)$ were resuspended into sterile $0.9 \%$ saline solution without BSA. The cell suspension was centrifuged at $2000 \mathrm{rpm}$ for $2 \mathrm{~min}$ to get platelet pellets which were dissolved in $13.8 \%$ ultra-pure $\mathrm{HNO}_{3}$ and left for 75 minutes at $90^{\circ} \mathrm{C}$. The lysed cells were stored at $-20^{\circ} \mathrm{C}$ until measurements of $\mathrm{Zn}^{2+}, \mathrm{Fe}^{2+}, \mathrm{Ca}^{2+}$ and $\mathrm{Mg}^{2+}$ ion levels with ICP-MS (iCAP $R Q$, ThermoFisher Scientific, Waltham, USA). Before the measurements, the lysates were diluted 1:20 into ultra-pure water to be at final concentration of $0.69 \% \mathrm{HNO}_{3}$. Five standard solutions were prepared individually for each element containing 10, 1, 0.1, 0.01 and 0.001 $\mathrm{mg} / \mathrm{l}$ of $\mathrm{Zn}^{2+} / \mathrm{Fe}^{2+} / \mathrm{Ca}^{2+}$ ions or $100,10,1,0.1$ and $0.01 \mathrm{mg} / \mathrm{l} \mathrm{Mg}{ }^{2+}$ ions (Sigma-Aldrich, Merck $\mathrm{KGaA}$, Darmstadt Germany). The blank containing $0.69 \% \mathrm{HNO}_{3}$ was subtracted from each standard solution and sample. The internal Rh standard (Sigma-Aldrich, Merck KGaA, Darmstadt Germany) with a concentration of $10 \mu \mathrm{g} / \mathrm{l}$ was automatically added to each sample by the ICP-MS device. The measured ion concentration in $\mathrm{mg} / \mathrm{l}$ was multiplied with 20 , which means that the displayed ion concentration corresponds to the concentration in the cell lysate solution in $13.8 \% \mathrm{HNO}_{3}$.

\section{Measurement of free intracellular $\mathrm{Zn}^{2+}$ levels in platelets}

Washed platelets $\left(5 \times 10^{5}\right.$ cells $/ \mu$ l) were loaded with FluoZin- $3(2 \mu \mathrm{M})$ for 30 min at $37^{\circ} \mathrm{C}$ in the dark. Fluorophore-loaded platelets were washed, centrifuged at $2000 \mathrm{rpm}$ for $2 \mathrm{~min}$ and resuspended with Tyrode's HEPES buffer. $25 \mu$ l of loaded platelets were diluted with $1 \mathrm{ml}$ of Tyrode's HEPES buffer. Fluorescence intensity was recorded for an initial $50 \mathrm{sec}$ to get basal $\mathrm{Zn}^{2+}$ levels in non-loaded platelet (background F0) and for another $50 \mathrm{sec}$ for loaded platelets (untreated F1). Then, thrombin $(0.02 \mathrm{U} / \mathrm{ml})$ was added to the loaded platelet suspension and fluorescence intensity was recorded for another $300 \mathrm{sec}$ (treated F2). The measurements were performed on a BD FACSCelesta (Becton Dickinson). Results were analysed by FlowJo Software (TreeStar, USA) to measure geometric mean fluorescence intensity (Geo-MFI). Retained free intracellular $\mathrm{Zn}^{2+}$ after stimulation was determined as percent of (F2-F0)/(F1F0).

\section{Flow cytometric analysis of platelet integrin activation, degranulation and glycoprotein expression}

Measurement of platelet glycoprotein expression has been described recently (39). Briefly, 50

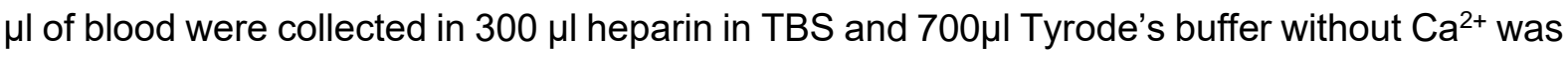
added. $50 \mu$ of diluted blood were stained for $15 \mathrm{~min}$ at RT with saturating amounts of fluorophore-conjugated antibodies and analysed directly after addition of $500 \mu \mathrm{l}$ PBS. To analyse platelet activation responses, blood samples were washed twice $(2,800 \mathrm{rpm}, 5 \mathrm{~min}$, $\mathrm{RT}$ ) in Tyrode's buffer without $\mathrm{Ca}^{2+}$ and finally resuspended in Tyrode's buffer containing 2 $\mathrm{mM} \mathrm{Ca}{ }^{2+}$. Platelets were activated with appropriately diluted agonists for $8 \mathrm{~min}$ at $37^{\circ} \mathrm{C}$ followed by $8 \mathrm{~min}$ at RT in the presence of saturating amounts of PE-coupled JON/A (4H5, Emfret Analytics) detecting activated $\alpha_{\| 1} \beta_{3}$ integrin and FITC-coupled anti-P-selectin (Wug.E9, 
Emfret Analytics) antibodies in the dark. The reaction was stopped by addition of $500 \mu \mathrm{I}$ PBS and samples were analysed with a BD FACSCelesta. Platelets were identified by their forward/side scatter (FSC/SSC) characteristics. Obtained data was analysed using FlowJo (TreeStar, Ashland, OR, USA). Mean fluorescence intensities were normalized to background fluorescence of unstained platelets.

\section{Aggregometry}

$200 \mu \mathrm{l}$ of washed platelets in Tyrode's buffer containing $2 \mathrm{mM} \mathrm{Ca}^{2+}$ at a concentration of $2 \times 10^{5}$ platelets/ $\mu \mathrm{l}$, were transferred into a cuvette. For all measurements with washed platelets, except those with thrombin as agonist, Tyrode's buffer was supplemented with $100 \mu \mathrm{g} / \mathrm{ml}$ human fibrinogen. Agonists were added as 100-fold concentrates and light transmission was recorded over 10 min with an Apact 4-channel optical aggregation system (APACT, Hamburg, Germany). For calibration of each measurement, Tyrode's buffer was set as $100 \%$ aggregation and washed platelet suspension was set as $0 \%$ aggregation, before the agonist was added.

\section{Adhesion and spreading assay}

Ibidi $\mu$-Slide 8 Well chamber was coated with $100 \mu \mathrm{g} / \mathrm{ml}$ human fibrinogen at $4^{\circ} \mathrm{C}$ overnight and blocked for at least $1 \mathrm{~h}$ at RT with $1 \%$ BSA in sterile PBS. The wells were rinsed with Tyrode's buffer and $300 \mu \mathrm{l}$ washed platelets $(250,000$ cells/ $\mu$ in Tyrode's containing $2 \mathrm{mM}$ $\left.\mathrm{Ca}^{2+}\right)$ were stimulated with thrombin $(0.01 \mathrm{U} / \mathrm{ml})$ and immediately added to the fibrinogen surface. Platelets were allowed to adhere and spread at $37^{\circ} \mathrm{C}$ for $10 \mathrm{~min}$. The non-adhered platelets were washed away and the adhered cells were fixed by addition of $300 \mu \mathrm{l} 4 \%$ PFA/PBS for $10 \mathrm{~min}$ at RT. Then, the wells were washed twice with $300 \mu \mathrm{l}$ PBS. Platelets were visualized by differential interference contrast (DIC) microscopy with a Zeiss Axiovert 200 inverted microscope (100x/1.4 oil objective). Representative images were taken using a CoolSNAP-EZ camera (Visitron, Munich, Germany) and evaluated according to different platelet spreading stages with ImageJ (National Institutes of Health, Bethesda, MD, USA). Spreading stages were defined as follows: 1: round; no filopodia, no lamellipodia. 2: only filopodia. 3: lamellipodia; full spreading

\section{Collagen flow chamber assay}

Coverslips (24×60 mm) were coated with $200 \mu \mathrm{g} / \mathrm{ml}$ fibrillar type-I collagen (Horm) overnight at $37^{\circ} \mathrm{C}$ and blocked for $1 \mathrm{~h}$ with $1 \%$ BSA at RT. Blood $(700 \mu \mathrm{l})$ was collected into $300 \mu \mathrm{l}$ heparin in TBS $(20 \mathrm{U} / \mathrm{ml}, \mathrm{pH}$ 7.3) and two parts of blood were diluted with one part Tyrode's buffer with $2 \mathrm{mM} \mathrm{Ca}^{2+}$. Platelets were labelled with a DyLight-488 conjugated anti-GPIX Ig derivative $\left(0.2 \mu \mathrm{g} / \mathrm{ml}\right.$; Emfret Analytics) for $5 \mathrm{~min}$ at $37^{\circ} \mathrm{C}$. The diluted blood was filled into a 1 $\mathrm{ml}$ syringe and connected to a transparent flow chamber with a slit depth of $50 \mu \mathrm{m}$, equipped with the coated coverslips. Perfusion was performed using a pulse-free pump under high shear stress equivalent to a wall shear rate of $1,000 \mathrm{~s}-1$ for $4 \mathrm{~min}$. Thereafter, coverslips were washed by a 4 min perfusion with Tyrode's buffer at the same shear rate and phase-contrast and fluorescent images were recorded from at least five different fields of view (63x objective) using a Leica DMI6000 microscope. Image analysis was performed using Image $\mathrm{J}(\mathrm{NIH})$. Thrombus formation was expressed as the mean percentage of the total area covered by 
thrombi (= surface coverage) and as the mean integrated fluorescence intensity (= thrombus volume).

\section{Measurements of intracellular $\mathrm{Ca}^{2+}$ levels}

Washed platelets were adjusted to a concentration of approximately $2.5 \times 10^{5} / \mu \mathrm{l}$ in $\mathrm{Ca}^{2+}$-free Tyrode's buffer. $100 \mu \mathrm{l}$ of this suspension were loaded with $3 \mu \mathrm{M}$ fura-2-AM F-127 for 25 min at $37^{\circ} \mathrm{C}$. After labelling, the platelets were washed once and resuspended in $500 \mu$ l Tyrode's buffer containing $1 \mathrm{mM} \mathrm{Ca}^{2+}$ for measurement of $\mathrm{Ca}^{2+}$ influx. This cell suspension was transferred into a cuvette and fluorescence was measured with a PerkinElmer LS 55 fluorimeter (Perkin Elmer, Waltham, MA, USA) under stirring conditions. Excitation was switched between 340 and $380 \mathrm{~nm}$ and emission was measured at $509 \mathrm{~nm}$. Basal $\mathrm{Ca}^{2+}$ levels were recorded for $50 \mathrm{~s}$ before the indicated agonist was added. Each measurement was calibrated using $1 \%$ Triton X-100 and EGTA.

\section{Intravital microscopy of $\mathrm{FeCl}_{3}$-injured mesenteric arterioles}

Mice (16 - $19 \mathrm{~g}$ body weight) were anaesthetized and the mesentery was exteriorized through a midline abdominal incision. Arterioles free of fat tissues with a diameter of $35-60 \mu \mathrm{m}$ were visualized using a Zeiss Axiovert 200 inverted microscope (10x/0.25 air objective) equipped with a $100 \mathrm{~W}$ HBO fluorescent lamp and a CoolSNAP-EZ camera. Injury was induced by topical application of a $3 \mathrm{~mm}^{2}$ filter paper saturated with $20 \% \mathrm{FeCl}_{3}$. Adhesion and aggregation of fluorescently labelled platelets (achieved by previous intravenous injection of a DyLight-488 conjugated anti-GPIX Ig derivative; Emfret Analytics) in arterioles was monitored for 40 min or until complete occlusion occurred (blood flow stopped for $>1 \mathrm{~min}$ ). Digital images were recorded and analysed using MetaMorph software.

\section{Western blotting}

Washed platelets were adjusted at concentration of $4 \times 10^{5} / \mu \mathrm{l}$ in BSA- and $\mathrm{Ca}^{2+}$-free Tyrode's buffer and supplemented with apyrase (2 $\mathrm{mM}$ f.c.). Under stirring conditions in an aggregometer at $37^{\circ} \mathrm{C}$, platelets were stimulated with different agonists as indicated in the figures. The stimulation was stopped by mixing the platelet suspension with $10 x$ concentrated ice-cold cell lysis buffer (1x f.c., Cell Signaling Technology \#9803) containing Pefabloc SCProtease-Inhibitor and phosphatase inhibitors (Carl Roth) and kept on ice for at least $30 \mathrm{~min}$. Afterwards, platelet lysates were mixed with $4 \mathrm{x}$ SDS sample buffer (1x f.c.), boiled for 5 minutes and subjected to Western blot analysis. Samples were separated by SDS-PAGE using the $10 \%$ gel system for electrophoresis, followed by transfer onto a PVDF membrane. Membranes were blocked for 10 minutes in 10\% BSA in TBS-T and then incubated overnight at $4^{\circ} \mathrm{C}$ with the indicated antibodies obtained from Cell Signaling Technology (phospho-PKC Substrate Motif (\#6967), phospho-p42/44 MAPK (\#4370), total p42/44 (\#9102), $\beta$-actin (\#3700)). Afterwards, the membrane was washed three times with TBS-T at RT. Next, the membranes were incubated with the appropriate secondary HRP-labelled antibodies (CST \#7074 or \#7076) for $1 \mathrm{~h}$ at RT. Finally, the membranes were washed several times and proteins were visualized using the Clarity ${ }^{\mathrm{TM}}$ Western ECL Substrate (Bio-Rad) and the ChemiDoc Imaging System (Bio-Rad). 


\section{Statistical analysis}

The shown data are expressed as mean \pm SEM. When applicable, a modified Student's t-test was used to analyse differences between unpaired two group's data. For analysis of more than two groups, one-way Anova or two-way Anova for repeated measures followed by the Bonferroni multiple comparison post-hoc test was applied. $p$-values $<0.05$ were considered as statistically significant $\left({ }^{\star}\right), p<0.01\left(^{* *}\right)$ and $p<0.001\left(^{* * *}\right)$.

\section{Results}

\section{$\mathrm{Zn}^{2+}$ homeostasis is disturbed in platelet lacking ZIP1 and ZIP3 transporters}

Several studies indicated the essential role of $\mathrm{Zn}^{2+}$ in the regulation of platelet activity and signalling $(19,20)$. However, the transport mechanisms that control intracellular levels of $\mathrm{Zn}^{2+}$ in platelets and their relevance for platelet function remained unaddressed. Our previous study indicated that several members of ZIP (SIc39a) family of transporters, which regulate the import of $\mathrm{Zn}^{2+}$ into the cytosol (25), are expressed in MKs (7). RNA analysis indicated that ZIP1 and ZIP3 were among the most highly expressed transporters in MKs during the differentiation and maturation stages (7). Therefore, we used a previously described mouse model globally lacking the expression of ZIP1 and ZIP3 transporters (ZIP1/3 DKO) (37). Quantitative RT-PCR analyses clearly demonstrated that in vitro differentiated MKs of the double knock-out mice are deficient for the expression of Slc39a1 and Slc39a3 (genes encoding ZIP1 and ZIP3, respectively) (Fig. 1A). ZIP1/3 DKO mice showed unaltered blood cell (WBCs, RBCs) and platelet counts as compared to wild-type (WT) animals. However, there was a slight but significant reduction in platelet size in ZIP1/3 DKO mice (SuppI Fig. 1).

Since ZIP1 and ZIP3 act as importers to promote $\mathrm{Zn}^{2+}$ influx into the cytosol, we determined total levels of intracellular $\mathrm{Zn}^{2+}$ (protein-bound and labile) by inductively coupled plasma mass spectrometry (ICP-MS). No significant differences were found for overall $\left[\mathrm{Zn}^{2+}\right]_{i}$ or other divalent cations $\left(\left[\mathrm{Ca}^{2+}\right]_{i},\left[\mathrm{Mg}^{2+}\right]_{i},\left[\mathrm{Fe}^{2+}\right]_{i}\right) \quad$ (Fig. 1B). To determine the relative ratio of free intracellular $\mathrm{Zn}^{2+}$, WT and ZIP1/3 DKO washed platelets were incubated with the $\mathrm{Zn}^{2+}$-specific cell permeable fluorescent dye Fluo-Zin3. ZIP1/3 DKO mice express low levels of GFP from the S/c39a1 and S/c39a3 gene locus (37) which makes it difficult to compare the basal amount of free $\left[\mathrm{Zn}^{2+}\right]_{i}$ in WT vs DKO mice. The lack of other commercially available specific $\mathrm{Zn}^{2+}$ fluorophores, however, necessitated its usage. Despite the slight increase in background fluorescence, it is apparent that platelets from DKO mice contain significant amounts of FluoZin3-stainable $\left[\mathrm{Zn}^{2+}\right]_{i}$ (Fig. 1C), which interestingly, is not as efficiently released from the cells in response to thrombin $(0.02 \mathrm{U} / \mathrm{ml})$ as in WT platelets (Fig. 1D). While WT platelets retained only $24.12 \% \pm 2.942(n=10)$ of the initial background corrected FluoZin3 fluorescence, ZIP1/3 DKO platelets retained 39.12\% $\pm 2.766(n=11 ; p<0.01)$.

\section{Platelets lacking ZIP1 and ZIP3 transporters are hyperreactive to GPCR agonists}

Activated platelets release $\mathrm{Zn}^{2+}$ into the circulation to modulate proteins that play a major role in platelet adhesion and aggregation (10-13). Previous studies have indicated that $\mathrm{Zn}^{2+}$ can act as agonist or second messenger to modulate platelet reactivity in a concentrationdependent manner $(19,20)$. Taken in consideration that disturbed $\left[\mathrm{Zn}^{2+}\right]_{i}$ alters platelet 
function, we evaluated the aggregation phenotype of platelets lacking ZIP1 and ZIP3 transporters. Interestingly, ZIP1/3 DKO mice displayed an enhanced platelet aggregation in response to threshold concentrations of GPCR agonists such as thrombin $(0.003 \mathrm{U} / \mathrm{ml})$, ADP $(0.5 \mu \mathrm{M})$ and $\mathrm{U} 46619(0.2 \mu \mathrm{M})$ (Fig.2A). However, in response to collagen or collagen-related peptide (CRP) (Fig.2B), agonists of the ITAM-coupled receptor glycoprotein (GP)VI, there was no difference in platelet aggregation between ZIP1/3 DKO and their corresponding WT controls. This suggested that loss of ZIP1/3 might selectively alter GPCR-coupled signalling in activated platelets.

To corroborate this hypothesis, we measured activation of $\alpha_{\| 1 b} \beta_{3}$ integrin using the JON-A/PE antibody, which only binds $\alpha_{11 b} \beta_{3}$ in its active conformation, in flow cytometry (Fig. 3A-C). Our analysis showed that ZIP1/3 deficiency promoted $\alpha_{11 b} \beta_{3}$ integrin activation in response to threshold concentrations of thrombin $(0.002 \mathrm{U} / \mathrm{ml})$ (Fig.3A), however, responses to ADP, the thromboxane A2 (TXA2) analogue U46619 (Fig. 3B) or the ITAM receptor agonist CRP (Fig.3C) were unaffected. Similar observations were made for P-selectin exposure (Fig. 3DF). These results indicated that ZIP1 and ZIP3 transporters might be more involved in the regulation of PAR signalling pathway to mediate platelet aggregation. Of note, there was no difference in the total expression levels of integrins $\left(\alpha_{\| b} \beta_{3}, \alpha 5\right.$ and $\left.\alpha 5\right)$ in platelets from ZIP1/3 DKO and WT mice (Suppl Fig.2A). Similarly, no difference was detected in the surface expression levels of the GPIb-V-IX complex (Suppl Fig. 2B), CD9, CLEC2 and GPVI (Suppl Fig. 2C).

Since it has been reported that intracellular $\mathrm{Zn}^{2+}$ concentrations regulate platelet shape changes (19), we tested platelet adhesion and spreading on fibrinogen in the presence of thrombin under static conditions. However, platelets isolated from ZIP1/3 DKO mice did not show any difference in adhesion and spreading compared to WT mice (Fig.4A, B).

\section{ZIP1/3 deficiency increases $\mathrm{Ca}^{2+}$ influx and PKC activation in platelets}

It has been speculated that $\mathrm{Ca}^{2+}$ and $\mathrm{Zn}^{2+}$ may work synergistically to induce platelet activation (20). Even though overall $\left[\mathrm{Ca}^{2+}\right]_{i}$ appeared to be equivalent in WT and ZIP1/3 DKO platelets at resting conditions in the absence of extracellular $\mathrm{Ca}^{2+}$ as determined by ICP-MS (Fig. 1B), $\mathrm{Ca}^{2+}$ influx was significantly enhanced in ZIP1/3 DKO mice in response to thrombin $(0.01 \mathrm{U} / \mathrm{ml})$ (Fig. 5A), while $\mathrm{Ca}^{2+}$ influx in response to CRP was unaffected (Fig. 5B). Given the increase in $\mathrm{Ca}^{2+}$ influx in response to thrombin (Fig. 5A) and the fact that increased $\left[\mathrm{Zn}^{2+}\right]_{\mathrm{i}}$ has been shown to modulate protein kinase C (PKC) (20), we assessed the importance of platelet ZIP/ZIP3 in agonist-mediated activation of PKC by determination of the phosphorylation status of PKC substrates using Western blot analyses. Deletion of ZIP1/3 resulted in elevated phosphorylation levels of PKC substrates in response to $0.003 \mathrm{U} / \mathrm{ml}$ thrombin (Fig. 6A), 0.5 $\mu \mathrm{M}$ ADP (Fig. 6B) and to a lesser extent to $0.2 \mu \mathrm{M} U 46619$ (Fig. 6C) in stimulated platelets compared to platelets from WT mice. As observed in other assays before, the ITAM receptor agonists CRP $(0.1 \mu \mathrm{g} / \mathrm{ml})$ (Fig. 6D) or collagen $(1 \mu \mathrm{g} / \mathrm{ml})$ (Fig. 6E) did not induce a stronger phosphorylation of PKC substrates in platelets from ZIP1/3 DKO compared to WT platelets. Therefore, the presence of ZIP1 and ZIP3 transporters appears to increase GPCR's sensitivity to their respective agonists. 


\section{Deficiency of ZIP1/3 transporters promotes thrombus formation}

$\mathrm{Zn}^{2+}$ is considered to be an important contributor to haemostasis and thrombosis (17). According to this information and with respect to the observed hyperreactivity in aggregation (Fig. 2A), it was essential to determine the thrombotic potential ex vivo and in vivo in WT and ZIP1/3 DKO mice. In an ex vivo flow chamber assay, in which whole blood was perfused over collagen-coated coverslips at a shear rate of $1000 \mathrm{~s}^{-1}$, we observed significantly bigger stable 3-dimensional platelet aggregates in case of blood from ZIP1/3 DKO mice, while surface coverage was only mildly affected (Fig. 7A). Consistent with these ex vivo findings, ZIP1/3 DKO mice formed clearly visible thrombi at earlier time points in vivo upon $\mathrm{FeCl}_{3}$-mediated injury of mesenteric arteries. The formed thrombus occluded mesenteric arteries of ZIP1/3 DKO mice faster as compared to wild-type mice confirming that platelets from ZIP1/3 DKO mice are hyperactive (Fig. 7B).

\section{Discussion}

$\mathrm{Zn}^{2+}$ homeostasis is mainly controlled through $\mathrm{Zn}^{2+}$ transporting proteins and metallothionein. Transporters of the ZIP superfamily are widely expressed in eukaryotic cells to import $\mathrm{Zn}^{2+}$ into the cytoplasm while $\mathrm{ZnT}$ proteins export $\mathrm{Zn}^{2+}$ out of the cytoplasm $(31,32)$. The role of ZIP transporters in platelets, however, remained ill-defined. Interestingly, the global deletion of ZIP1 and ZIP3 provided the first direct proof that ZIP transporters are involved in the regulation of $\mathrm{Zn}^{2+}$ homeostasis in hippocampal neurons (40). The present study is, to our knowledge, the first to investigate the importance of ZIP transporters for platelet $\mathrm{Zn}^{2+}$ homeostasis and activation. Utilizing mice which globally lack ZIP1 and ZIP3, we provide evidence that these transporters selectively contribute to the control of platelet sensitivity towards GPCR agonists without affecting ITAM receptor agonists. Since ZIP1/3 DKO mice did not display alterations in platelet count, we conclude that megakaryopoiesis is independent of the presence of these transporters. Similarly, we did not observe any defects in other blood cells which is in line with the initial description of the mouse line (37). Due to the lack of specificity of all tested commercially available antibodies to detect ZIP1 and ZIP3, we confirmed the deletion of ZIP1 and ZIP3 by qPCR analysis in MKs generated in vitro from haematopoietic stem cells. We found that the deficiency of ZIP1 and ZIP3 altered $\mathrm{Zn}^{2+}$ homeostasis in platelets. While WT platelets release substantial amounts of free intracellular $Z^{2+}$ in response to thrombin, platelets from ZIP1/3 DKO mice showed a significantly delayed and less efficient release. As a net result the free $\left[\mathrm{Zn}^{2+}\right]_{i}$ remained higher in thrombin-treated platelets from ZIP1/3 DKO mice. Potential mechanisms underlying the delayed and ineffective reduction of intracellular free $\mathrm{Zn}^{2+}$ in ZIP1/3 DKO platelets might involve a dysregulated expression or activity of ZnT export transporters or defective release of granules. A general defect in a-granule release, however, can be excluded since the exposure of $\mathrm{P}$-selectin is even increased in response to thrombin in ZIP1/3-deficient platelets. Interestingly, recent work indicated that a-granules might not represent a homogeneous population of organelles, but rather comprise a group of subcellular compartments with unique composition and ultrastructure which might even release their content in an ordered manner (41-43). Whether ZIP1/3 may contribute to a selective release of platelet granules needs to be addressed in future experiments.

Not much is known about the downstream signalling mechanism by which ZIP1 and ZIP3 transporters control platelet activity. The hyper-responsiveness of platelet lacking ZIP1 and 
ZIP3 might be attributed to the increased retained pool of free intracellular $\mathrm{Zn}^{2+}$ which can act as a second messenger to enhance tyrosine phosphorylation events as shown in platelets (20), but also in nucleated cells, in particular mast cells (44), or might directly impact redox signalling (45). In addition, the enhanced $\mathrm{Ca}^{2+}$ entry in response to thrombin might likely affect a number or downstream signalling pathways. A common signalling molecule on which $\mathrm{Zn}^{2+}$ and $\mathrm{Ca}^{2+}$ pathways converge is PKC. It has been reported that $\mathrm{Zn}^{2+}$ augments $\mathrm{PKC}$ activity via increasing its association with regulatory ligand in lymphocytes and platelets (23). Besides $\mathrm{Zn}^{2+}, \mathrm{Ca}^{2+}$ activates PKC to regulate PS exposure in platelets(46). Clearly, there was an increased activation of PKC in ZIP1/3-deficient platelets in response to GPCR agonists, but not ITAM-coupled receptor agonists. According to these findings, there is a potential role of ZIP1 and ZIP3 in orchestrating GPCR signalling pathways in platelets. Taken in consideration that PKC is essential for thrombus formation (47), PKC activation could explain the observed promoted thrombus formation in ZIP1/3 DKO mice. Given that PKC activation also mediates platelet granule secretion $(47,48)$, the data are consistent with the selective increase of $\mathrm{P}$ selectin in platelets from ZIP1/3 DKO mice in response to GPCR agonists, particularly thrombin. Besides granule secretion, PKC activation is a positive regulator of integrin activation (49). Indeed, flow cytometric analyses confirmed an increased activation of $\alpha_{11 b} \beta_{3}$ in response to thrombin stimulation in ZIP1/3 DKO platelets which is in line with its role to promote platelet aggregation.

In aggregometry experiments as well as in flow cytometry experiments of $\alpha_{11 b} \beta_{3}$ integrin activation and degranulation, ZIP1/3-deficient platelets were hyperresponsive in response to threshold concentrations of GPCR agonists, but not towards agonists of the ITAM-coupled receptor GPVI, namely CRP and collagen. Nevertheless, platelets from ZIP1/3 DKO formed larger thrombi when perfused over a collagen-coated surface. This is most likely a consequence of second wave mediators, like TxA2 and ADP, which are generated and released upon platelet activation and amplify platelet activation via GPCR signalling in order to promote thrombus growth. Indeed, it has been shown that co-infusion of ADP and the stable TxA2 analogue U46619 into the flow chamber enhances thrombus formation (50), hence arguing that the observed phenotype is due to enhanced GPCR signalling of ZIP1/3 DKO platelets. Of note, thrombin does not contribute to this effect in this experimental setup since the presence of heparin in the flow chamber abolishes its activity. Alternatively, the prevailing shear forces and the presence of plasma factors might also contribute to the experimental outcomes. GPCR-mediated signalling pathways are also prevailing in our model of $\mathrm{FeCl}_{3}$ induced vessel injury (51-53), which is triggered by oxidative damage of vessel wall and blood cells and flocculation of blood proteins, while there is only limited, if any, collagen exposure inside the vessel $(52,54,55)$. Therefore, the enhanced thrombus formation in ZIP1/3 DKO mice is again in line with the hyperresponsiveness of their platelets towards GPCR agonists. Noteworthy, since a global KO model was used, we cannot exclude an impact of other cell types, e.g. endothelial cells and blood cells, as well as systemic alterations on the experimental outcome. An additional aspect that might also be of relevance is the role of $\mathrm{Zn}^{2+}$ in altering fibrin network structure and its mechanical properties (56). To what extent the altered $\mathrm{Zn}^{2+}$ release of ZIP1/3 DKO influences thrombus formation and stabilization via modification of the fibrin network in this assay warrants further investigation.

Taken together, our study for the first time attributes an important regulatory role to zinc transporters in platelet activation. In vivo, ZIP1/3 DKO mice develop faster occlusive thrombi 
in response to vascular injury. In vitro data show that platelets from ZIP1/3-deficient mice are hyperreactive to threshold concentrations of GPCR agonists, in particular thrombin, while responses to ITAM-coupled receptor agonists appear to be unaffected. Future studies are aimed at the understanding of the molecular mechanisms which determine this unexpected exclusiveness.

\section{Author contributions}

AE, PÖ, ME, FK, CK, UG, TV and HMH performed experiments and analysed data. BN discussed results and provided scientific input and technical equipment throughout the study. $\mathrm{MB}$ generated the mice. AE, TV, HMH wrote the manuscript with input from all the authors. $\mathrm{AE}$ and $\mathrm{HMH}$ conceived the study and designed research.

\section{Acknowledgements}

This work was supported by the Deutsche Forschungsgemeinschaft (DFG, German Research Foundation) (project number 374031971-TRR 240/project A09). We thank Donata Dorbath, Sandra Umbenhauer and Birgit Midloch for excellent technical assistance.

\section{References}

1. Saper, R. B., and Rash, R. (2009) Zinc: an essential micronutrient. Am Fam Physician 79, 768772

2. Andreini, C., Banci, L., Bertini, I., and Rosato, A. (2006) Counting the zinc-proteins encoded in the human genome. J Proteome Res 5, 196-201

3. Bafaro, E., Liu, Y., Xu, Y., and Dempski, R. E. (2017) The emerging role of zinc transporters in cellular homeostasis and cancer. Signal Transduct Target Ther 2

4. King, J. C., Shames, D. M., and Woodhouse, L. R. (2000) Zinc homeostasis in humans. J Nutr 130, 1360S-1366S

5. Krezel, A., and Maret, W. (2016) The biological inorganic chemistry of zinc ions. Arch Biochem Biophys 611, 3-19

6. Liang, X., Dempski, R. E., and Burdette, S. C. (2016) Zn(2+) at a cellular crossroads. Curr Opin Chem Biol 31, 120-125

7. Kiran Gotru, S., van Geffen, J. P., Nagy, M., Mammadova-Bach, E., Eilenberger, J., Volz, J., Manukjan, G., Schulze, H., Wagner, L., Eber, S., Schambeck, C., Deppermann, C., Brouns, S., Nurden, P., Greinacher, A., Sachs, U., Nieswandt, B., Hermanns, H. M., Heemskerk, J. W. M., and Braun, A. (2019) Defective $\mathrm{Zn}(2+)$ homeostasis in mouse and human platelets with alphaand delta-storage pool diseases. Sci Rep 9, 8333

8. Gorodetsky, R., Mou, X., Blankenfeld, A., and Marx, G. (1993) Platelet multielemental composition, lability, and subcellular localization. Am J Hematol 42, 278-283

9. Marx, G., Korner, G., Mou, X., and Gorodetsky, R. (1993) Packaging zinc, fibrinogen, and factor XIII in platelet alpha-granules. J Cell Physiol 156, 437-442

10. Mahdi, F., Madar, Z. S., Figueroa, C. D., and Schmaier, A. H. (2002) Factor XII interacts with the multiprotein assembly of urokinase plasminogen activator receptor, $\mathrm{gC} 1 \mathrm{qR}$, and cytokeratin 1 on endothelial cell membranes. Blood 99, 3585-3596

11. Stadler, N., Stanley, N., Heeneman, S., Vacata, V., Daemen, M. J., Bannon, P. G., Waltenberger, J., and Davies, M. J. (2008) Accumulation of zinc in human atherosclerotic lesions correlates with calcium levels but does not protect against protein oxidation. Arterioscler Thromb Vasc Biol 28, 1024-1030 
12. Sharir, H., Zinger, A., Nevo, A., Sekler, I., and Hershfinkel, M. (2010) Zinc released from injured cells is acting via the $\mathrm{Zn2}+$-sensing receptor, $\mathrm{ZnR}$, to trigger signaling leading to epithelial repair. J Biol Chem 285, 26097-26106

13. Bernardo, M. M., Day, D. E., Olson, S. T., and Shore, J. D. (1993) Surface-independent acceleration of factor XII activation by zinc ions. I. Kinetic characterization of the metal ion rate enhancement. J Biol Chem 268, 12468-12476

14. Magneson, G. R., Puvathingal, J. M., and Ray, W. J., Jr. (1987) The concentrations of free $\mathrm{Mg} 2+$ and free $\mathrm{Zn2}+$ in equine blood plasma. J Biol Chem 262, 11140-11148

15. Emery, M. P., Browning, J. D., and O'Dell, B. L. (1990) Impaired hemostasis and platelet function in rats fed low zinc diets based on egg white protein. J Nutr 120, 1062-1067

16. Stefanini, M. (1999) Cutaneous bleeding related to zinc deficiency in two cases of advanced cancer. Cancer 86, 866-870

17. Mammadova-Bach, E., and Braun, A. (2019) Zinc Homeostasis in Platelet-Related Diseases. Int J Mol Sci 20

18. Vu, T. T., Fredenburgh, J. C., and Weitz, J. I. (2013) Zinc: an important cofactor in haemostasis and thrombosis. Thromb Haemost 109, 421-430

19. Ahmed, N. S., Lopes Pires, M. E., Taylor, K. A., and Pugh, N. (2019) Agonist-Evoked Increases in Intra-Platelet Zinc Couple to Functional Responses. Thromb Haemost 119, 128-139

20. Watson, B. R., White, N. A., Taylor, K. A., Howes, J. M., Malcor, J. D., Bihan, D., Sage, S. O., Farndale, R. W., and Pugh, N. (2016) Zinc is a transmembrane agonist that induces platelet activation in a tyrosine phosphorylation-dependent manner. Metallomics 8, 91-100

21. Heyns Adu, P., Eldor, A., Yarom, R., and Marx, G. (1985) Zinc-induced platelet aggregation is mediated by the fibrinogen receptor and is not accompanied by release or by thromboxane synthesis. Blood 66, 213-219

22. Marx, G., Krugliak, J., and Shaklai, M. (1991) Nutritional zinc increases platelet reactivity. Am $J$ Hematol 38, 161-165

23. Forbes, I. J., Zalewski, P. D., Giannakis, C., Petkoff, H. S., and Cowled, P. A. (1990) Interaction between protein kinase $C$ and regulatory ligand is enhanced by a chelatable pool of cellular zinc. Biochim Biophys Acta 1053, 113-117

24. Turan, B., and Tuncay, E. (2017) Impact of Labile Zinc on Heart Function: From Physiology to Pathophysiology. Int J Mol Sci 18

25. Kambe, T., Taylor, K. M., and Fu, D. (2021) Zinc transporters and their functional integration in mammalian cells. J Biol Chem 296, 100320

26. Chevallet, M., Jarvis, L., Harel, A., Luche, S., Degot, S., Chapuis, V., Boulay, G., Rabilloud, T., and Bouron, A. (2014) Functional consequences of the over-expression of TRPC6 channels in HEK cells: impact on the homeostasis of zinc. Metallomics 6, 1269-1276

27. Monteilh-Zoller, M. K., Hermosura, M. C., Nadler, M. J., Scharenberg, A. M., Penner, R., and Fleig, A. (2003) TRPM7 provides an ion channel mechanism for cellular entry of trace metal ions. J Gen Physiol 121, 49-60

28. Sensi, S. L., Canzoniero, L. M., Yu, S. P., Ying, H. S., Koh, J. Y., Kerchner, G. A., and Choi, D. W. (1997) Measurement of intracellular free zinc in living cortical neurons: routes of entry. $J$ Neurosci 17, 9554-9564

29. Carter, R. N., Tolhurst, G., Walmsley, G., Vizuete-Forster, M., Miller, N., and Mahaut-Smith, M. P. (2006) Molecular and electrophysiological characterization of transient receptor potential ion channels in the primary murine megakaryocyte. J Physiol 576, 151-162

30. Roberts, D. E., Matsuda, T., and Bose, R. (2012) Molecular and functional characterization of the human platelet $\mathrm{Na}(+) / \mathrm{Ca}(2+)$ exchangers. Br J Pharmacol 165, 922-936

31. Bin, B. H., Seo, J., and Kim, S. T. (2018) Function, Structure, and Transport Aspects of ZIP and ZnT Zinc Transporters in Immune Cells. J Immunol Res 2018, 9365747

32. Cousins, R. J., Liuzzi, J. P., and Lichten, L. A. (2006) Mammalian zinc transport, trafficking, and signals. J Biol Chem 281, 24085-24089

33. Kambe, T. (2012) Molecular architecture and function of ZnT transporters. Curr Top Membr 69, $199-220$ 
34. Burkhart, J. M., Vaudel, M., Gambaryan, S., Radau, S., Walter, U., Martens, L., Geiger, J., Sickmann, A., and Zahedi, R. P. (2012) The first comprehensive and quantitative analysis of human platelet protein composition allows the comparative analysis of structural and functional pathways. Blood 120, e73-82

35. Lu, Q., Haragopal, H., Slepchenko, K. G., Stork, C., and Li, Y. V. (2016) Intracellular zinc distribution in mitochondria, ER and the Golgi apparatus. Int J Physiol Pathophysiol Pharmacol 8, 35-43

36. Maret, W. (2000) The function of zinc metallothionein: a link between cellular zinc and redox state. J Nutr 130, 1455S-1458S

37. Dufner-Beattie, J., Huang, Z. L., Geiser, J., Xu, W., and Andrews, G. K. (2006) Mouse ZIP1 and ZIP3 genes together are essential for adaptation to dietary zinc deficiency during pregnancy. Genesis 44, 239-251

38. Takeo, T., and Nakagata, N. (2011) Reduced glutathione enhances fertility of frozen/thawed C57BL/6 mouse sperm after exposure to methyl-beta-cyclodextrin. Biol Reprod 85, 1066-1072

39. Heib, T., Hermanns, H. M., Manukjan, G., Englert, M., Kusch, C., Becker, I. C., Gerber, A., Wackerbarth, L. M., Burkard, P., Dandekar, T., Balkenhol, J., Jahn, D., Beck, S., Meub, M., Dutting, S., Stigloher, C., Sauer, M., Cherpokova, D., Schulze, H., Brakebusch, C., Nieswandt, B., Nagy, Z., and Pleines, I. (2021) RhoA/Cdc42 signaling drives cytoplasmic maturation but not endomitosis in megakaryocytes. Cell Rep 35, 109102

40. Qian, J., Xu, K., Yoo, J., Chen, T. T., Andrews, G., and Noebels, J. L. (2011) Knockout of Zn transporters Zip-1 and Zip-3 attenuates seizure-induced CA1 neurodegeneration. J Neurosci 31, 97-104

41. Italiano, J. E., Jr., Richardson, J. L., Patel-Hett, S., Battinelli, E., Zaslavsky, A., Short, S., Ryeom, S., Folkman, J., and Klement, G. L. (2008) Angiogenesis is regulated by a novel mechanism: pro- and antiangiogenic proteins are organized into separate platelet alpha granules and differentially released. Blood 111, 1227-1233

42. Klement, G. L., Yip, T. T., Cassiola, F., Kikuchi, L., Cervi, D., Podust, V., Italiano, J. E., Wheatley, E., Abou-Slaybi, A., Bender, E., Almog, N., Kieran, M. W., and Folkman, J. (2009) Platelets actively sequester angiogenesis regulators. Blood 113, 2835-2842

43. Heijnen, H., and van der Sluijs, P. (2015) Platelet secretory behaviour: as diverse as the granules ... or not? J Thromb Haemost 13, 2141-2151

44. Nakashima-Kaneda, K., Matsuda, A., Mizuguchi, H., Sasaki-Sakamoto, T., Saito, H., Ra, C., and Okayama, Y. (2013) Regulation of IgE-dependent zinc release from human mast cells. Int Arch Allergy Immunol 161 Suppl 2, 44-51

45. Lopes-Pires, M. E., Ahmed, N. S., Vara, D., Gibbins, J. M., Pula, G., and Pugh, N. (2021) Zinc regulates reactive oxygen species generation in platelets. Platelets 32, 368-377

46. Yang, H., Kim, A., David, T., Palmer, D., Jin, T., Tien, J., Huang, F., Cheng, T., Coughlin, S. R., Jan, Y. N., and Jan, L. Y. (2012) TMEM16F forms a Ca2+-activated cation channel required for lipid scrambling in platelets during blood coagulation. Cell 151, 111-122

47. Konopatskaya, O., Gilio, K., Harper, M. T., Zhao, Y., Cosemans, J. M., Karim, Z. A., Whiteheart, S. W., Molkentin, J. D., Verkade, P., Watson, S. P., Heemskerk, J. W., and Poole, A. W. (2009) PKCalpha regulates platelet granule secretion and thrombus formation in mice. J Clin Invest 119, 399-407

48. Konopatskaya, O., Matthews, S. A., Harper, M. T., Gilio, K., Cosemans, J. M., Williams, C. M., Navarro, M. N., Carter, D. A., Heemskerk, J. W., Leitges, M., Cantrell, D., and Poole, A. W. (2011) Protein kinase $C$ mediates platelet secretion and thrombus formation through protein kinase D2. Blood 118, 416-424

49. Harper, M. T., and Poole, A. W. (2010) Diverse functions of protein kinase $C$ isoforms in platelet activation and thrombus formation. $J$ Thromb Haemost 8, 454-462

50. Pleines, I., Elvers, M., Strehl, A., Pozgajova, M., Varga-Szabo, D., May, F., Chrostek-Grashoff, A., Brakebusch, C., and Nieswandt, B. (2009) Rac1 is essential for phospholipase C-gamma2 activation in platelets. Pflugers Arch 457, 1173-1185

51. Furie, B., and Furie, B. C. (2008) Mechanisms of thrombus formation. N Engl J Med 359, 938949 
52. Eckly, A., Hechler, B., Freund, M., Zerr, M., Cazenave, J. P., Lanza, F., Mangin, P. H., and Gachet, C. (2011) Mechanisms underlying FeCl3-induced arterial thrombosis. J Thromb Haemost 9, 779-789

53. Sambrano, G. R., Weiss, E. J., Zheng, Y. W., Huang, W., and Coughlin, S. R. (2001) Role of thrombin signalling in platelets in haemostasis and thrombosis. Nature 413, 74-78

54. Barr, J. D., Chauhan, A. K., Schaeffer, G. V., Hansen, J. K., and Motto, D. G. (2013) Red blood cells mediate the onset of thrombosis in the ferric chloride murine model. Blood 121, 3733-3741

55. Ciciliano, J. C., Sakurai, Y., Myers, D. R., Fay, M. E., Hechler, B., Meeks, S., Li, R., Dixon, J. B., Lyon, L. A., Gachet, C., and Lam, W. A. (2015) Resolving the multifaceted mechanisms of the ferric chloride thrombosis model using an interdisciplinary microfluidic approach. Blood126, 817-824

56. Xia, J., Cai, L. H., Wu, H., MacKintosh, F. C., and Weitz, D. A. (2021) Anomalous mechanics of Zn(2+)-modified fibrin networks. Proc Natl Acad Sci U S A 118

\section{Figure legends}

Figure 1: Platelets from ZIP1/3 DKO mice display a delayed and reduced release of free intracellular $\mathbf{Z n}^{2+}$ in response to thrombin. (A) Quantitative RT-PCR analysis of mRNA levels of Slc39a1 and Slc39a3 in megakaryocytes from wild-type (WT) and ZIP1/3 knockout mice (ZIP1/3 DKO). (B) Determination of intracellular amounts of $\mathrm{Zn}^{2+}, \mathrm{Ca}^{2+}, \mathrm{Mg}^{2+}$ and $\mathrm{Fe}^{2+}$ by ICP-MS analysis of washed platelets. (C) Retained intracellular levels of free $\mathrm{Zn}^{2+}$ determined by FluoZin3 fluorescence upon stimulation of WT or ZIP1/3 DKO platelets with thrombin $(0.02$ $\mathrm{U} / \mathrm{ml}, 5 \mathrm{~min}$ ). $\mathrm{n}=10-11$, (Students t-test), ${ }^{* * *} \mathrm{P}<0.0001$ (D) Representative graphs of FluoZin3 labelling of WT and ZIP1/3 DKO platelets before and after stimulation with thrombin $(0.02$ $\mathrm{U} / \mathrm{ml})$.

Figure 2: Platelets from ZIP1/3 DKO mice are hyperresponsive towards GPCR agonists but not to ITAM-coupled receptor agonists. Platelet aggregation was measured using Fibrintimer 4-channel aggregometer after the stimulation of washed platelets isolated from WT and ZIP1/3 DKO mice with (A) different GPCR agonists (thrombin, ADP, U46619) and (B) ITAM-coupled receptor agonists (collagen, CRP) using the indicated concentrations; $n=9-19$ (two-way ANOVA + Bonferroni), ${ }^{* *} \mathrm{P}<0.01$.

Figure 3: Analysis of platelet integrin activation and degranulation by flow cytometry. Platelets from WT and ZIP1/3 DKO mice were activated with either thrombin (A, D), ADP $(10 \mu \mathrm{M}), \mathrm{U} 46619(3 \mu \mathrm{M})$ and their combination $(B, E)$ or $\mathrm{CRP}(\mathrm{D}, \mathrm{F})$ and stained with saturating amounts of PE-coupled JON/A detecting activated $\alpha$ llbß3 integrin (A-C) or FITC-coupled anti$P$-selectin (D-F). Mean background fluorescence of unstained platelets was subtracted from all data sets. $\mathrm{n}=9-10$ (two-way ANOVA + Bonferroni), ${ }^{* * *} \mathrm{P}<0.001$

Figure 4: ZIP1/3 deficiency has no effect on in vitro platelet adhesion and spreading under static conditions. (A) Washed platelets from WT and ZIP1/3 DKO mice were allowed to adhere on fibrinogen for $10 \mathrm{~min}$ in the presence of $0.01 \mathrm{U} / \mathrm{ml}$ thrombin. (B) Quantification of spreading stages (round=no filopodia, no lamellipodia)

Figure 5: ZIP1/3 deficiency increases $\mathrm{Ca}^{2+}$ influx in response to thrombin but no effect in response to CRP. The increase in intracellular $\mathrm{Ca}^{2+}$ levels $\left(\left[\mathrm{Ca}^{2+}\right]_{i}\right)$ in washed platelets from WT and ZIP1/3 DKO mice stained with Fura-2 A/M after the stimulation with (A) Thrombin $(0.01 \mathrm{U} / \mathrm{ml})$ or $(B) \operatorname{CRP}(2 \mu \mathrm{g} / \mathrm{ml})$ in the presence of $1 \mathrm{mM} \mathrm{CaCl}_{2} ; \mathrm{n}=10-20$ (Students t-test), ${ }^{* * *} \mathrm{P}<0.001$ 
Figure 6: ZIP1/3 deficiency promotes PKC activation in murine platelets. Representative blots $(n=3-5)$ show the levels of the phosphorylation of PKC substrates under resting (0s) conditions or upon stimulation with the GPCR agonists $(A)$ Thrombin $(0.003 \mathrm{U} / \mathrm{ml}$ for $30 \mathrm{~s}$ and $60 \mathrm{~s})$; (B) ADP $(0.5 \mu \mathrm{M}$ for $10 \mathrm{~s}$ and $30 \mathrm{~s})$ or (C) U46619 $(0.2 \mu \mathrm{M}$ for $30 \mathrm{~s}$ and $60 \mathrm{~s})$, or the ITAMcoupled receptor agonists (D) CRP $(0.1 \mu \mathrm{g} / \mathrm{ml}$ for $60 \mathrm{~s}$ and $120 \mathrm{~s})$ or $(E)$ collagen $(1 \mu \mathrm{g} / \mathrm{ml}$ for $60 \mathrm{~s}$ and $120 \mathrm{~s})$. Staining against $\beta$-actin served as loading control.

Figure 7: ZIP1/3 deficiency promotes in vivo and in vitro thrombus formation. $(A)$ Adhesion and thrombus formation of platelets on collagen was assessed in a flow adhesion assay at a wall shear rate of 1000/s. Representative images and the quantification of the surface coverage and the relative thrombus volume are shown $\left(n=6\right.$; Students t-test; ${ }^{*}<<0.05$; Scale bar: $50 \mu \mathrm{m}$ ). (B) Representative images (left) and quantitative analysis (right) indicate the time for appearance of $1^{\text {st }}$ in vivo thrombus $(>10 \mu \mathrm{M})$ and time to occlusion at mesenteric arteries following induction of injury using $\mathrm{FeCl}_{3}$ ( $\mathrm{n}=6-7$ mice; each 2-3 arteries; Students ttest; ${ }^{*} \mathrm{P}<0.05,{ }^{* * *} \mathrm{P}<0.001$ ). 


\section{Figure 1 (Elgheznawy et al.)}

A
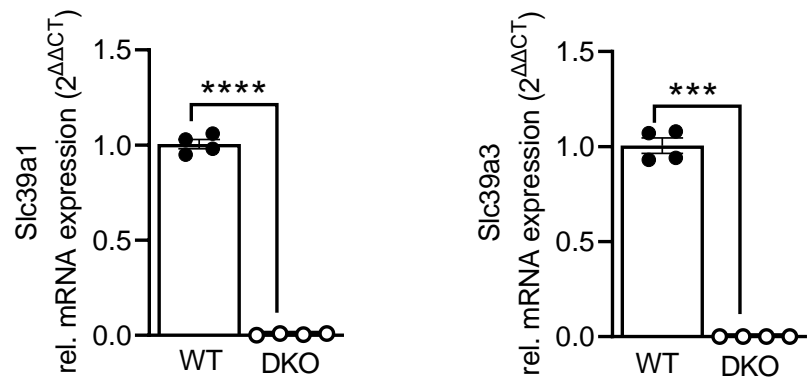

B
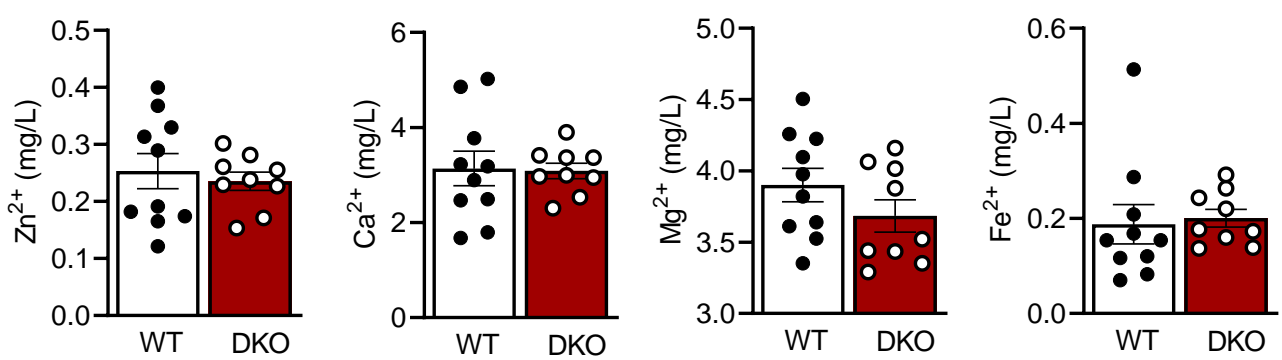

C

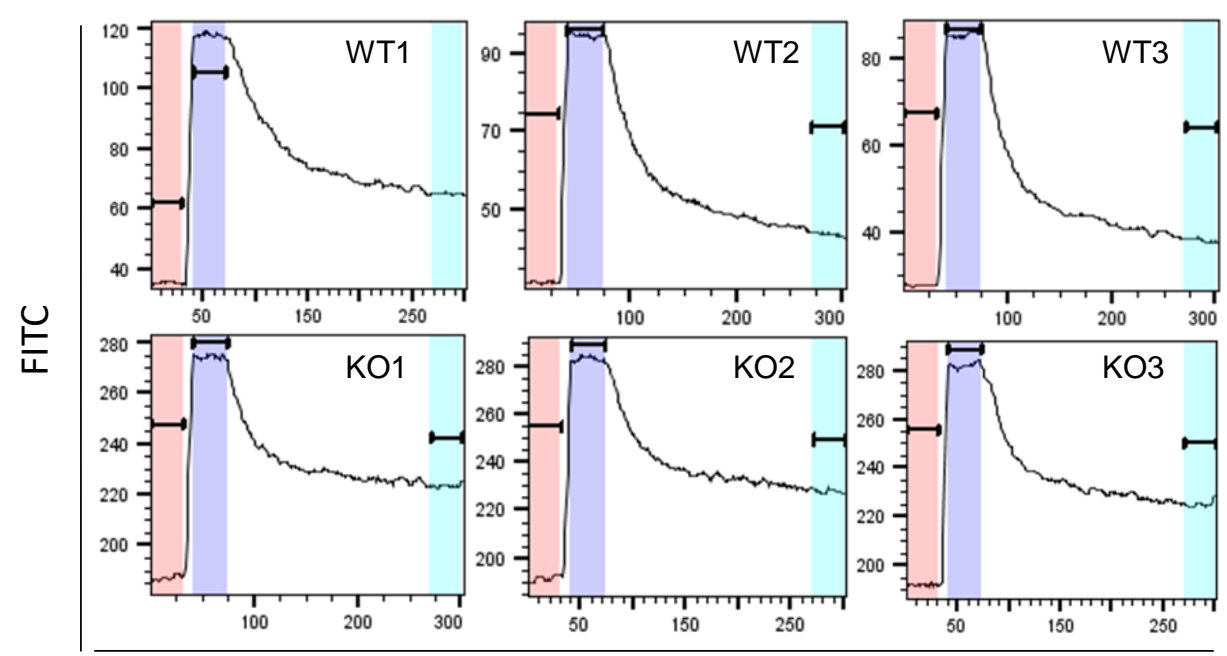

D

Time 
Figure 2 (Elgheznawy et al.)
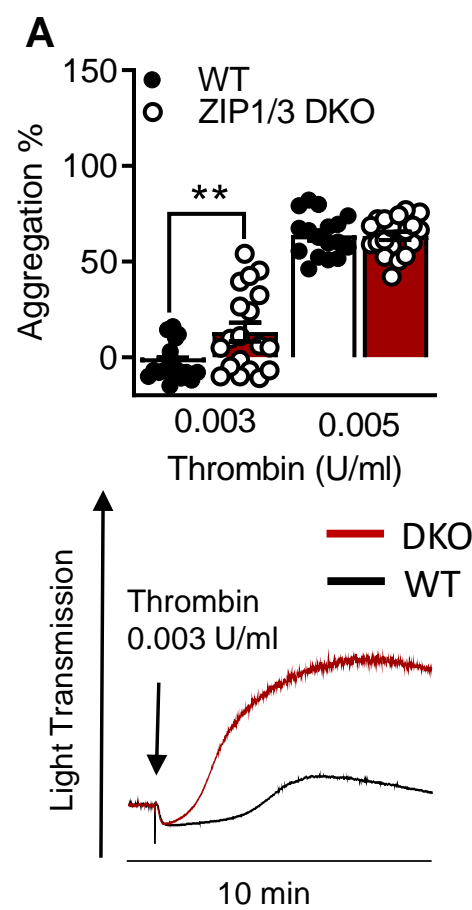

B
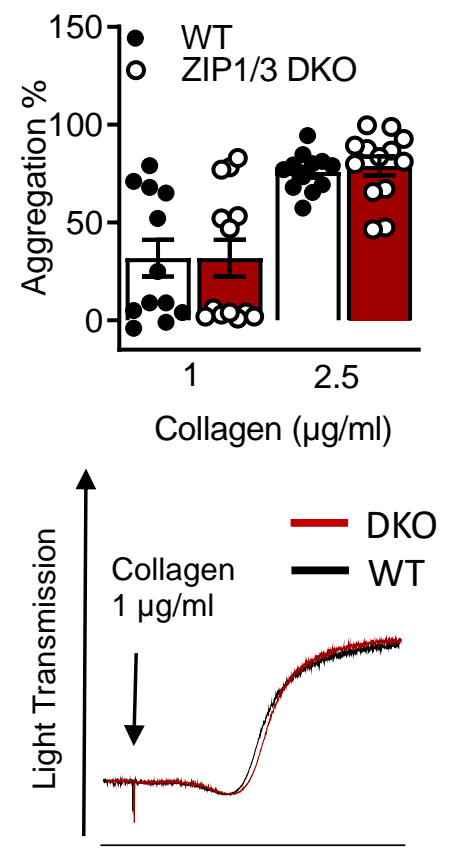

$10 \mathrm{~min}$
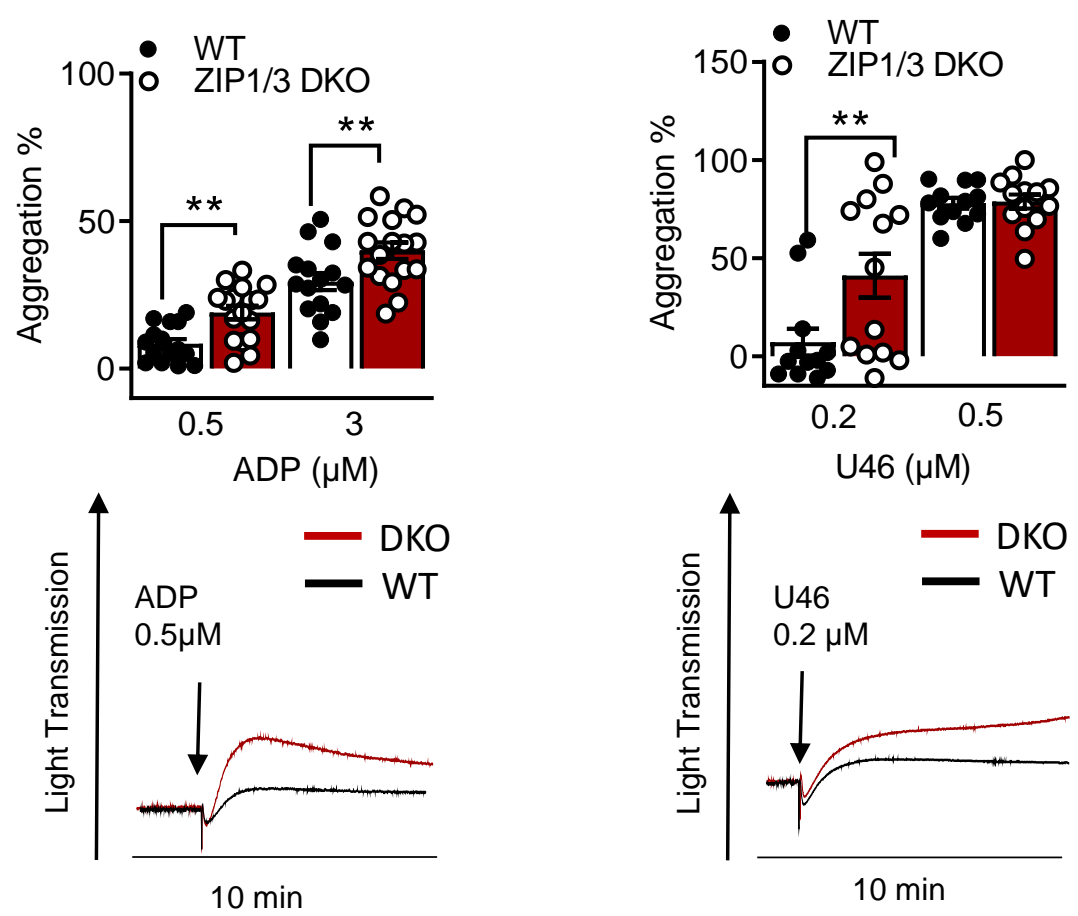

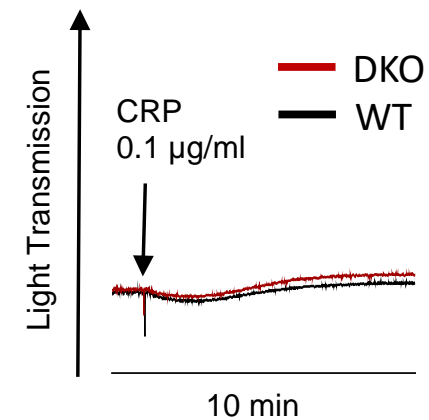


Figure 3 (Elgheznawy et al.)

A

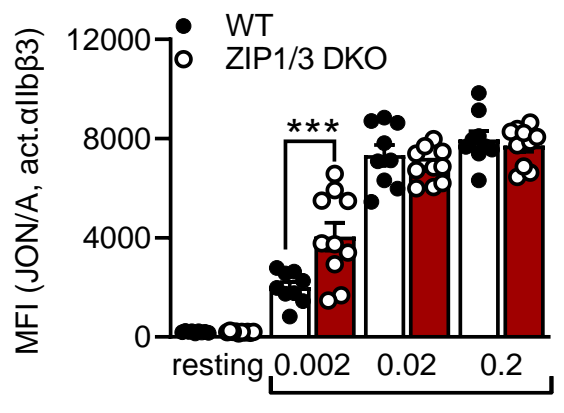

Thrombin (U/ml)

D

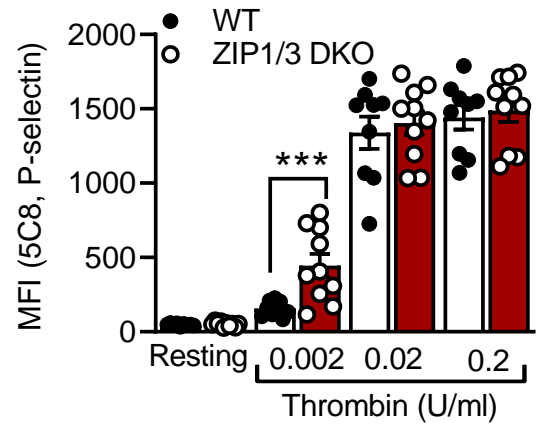

B

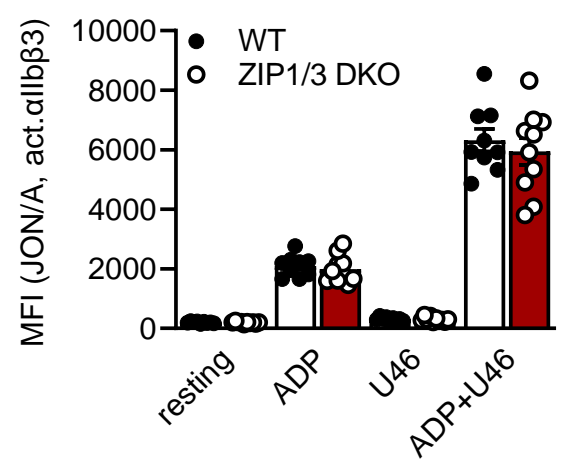

E

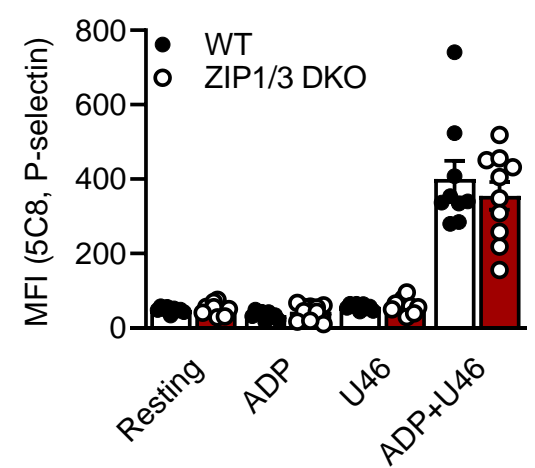

C

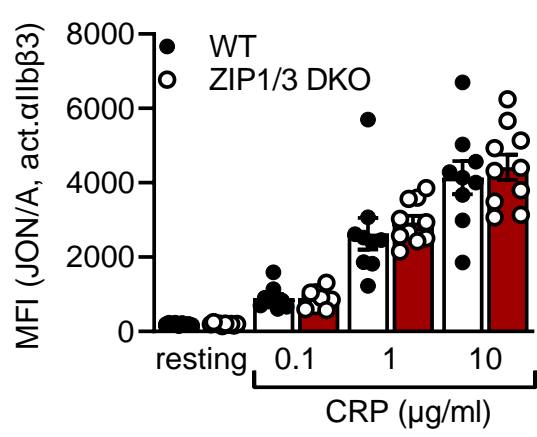

$\mathbf{F}$

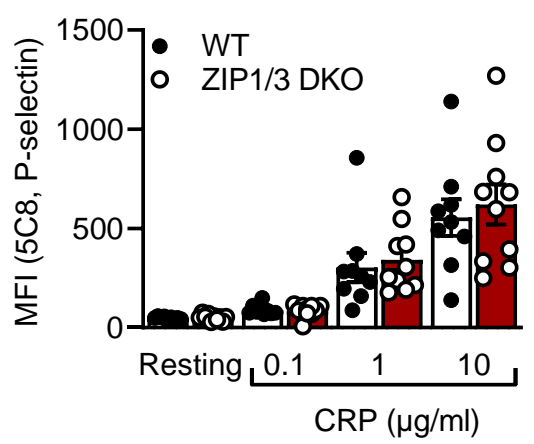


Figure 4 (Elgheznawy et al.)

A

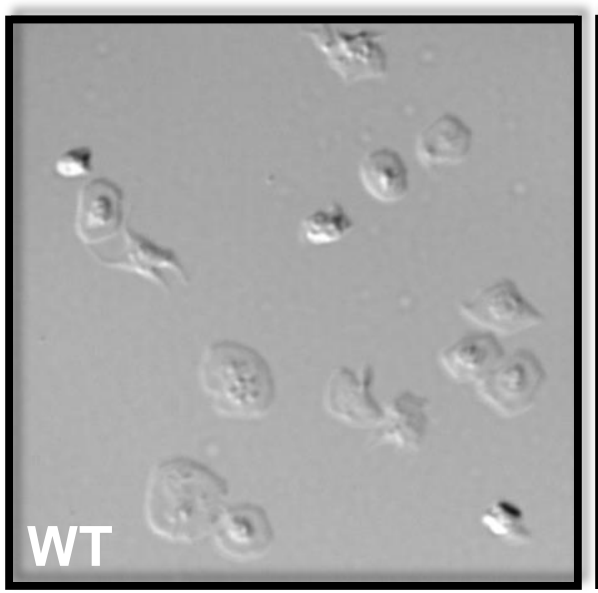

B

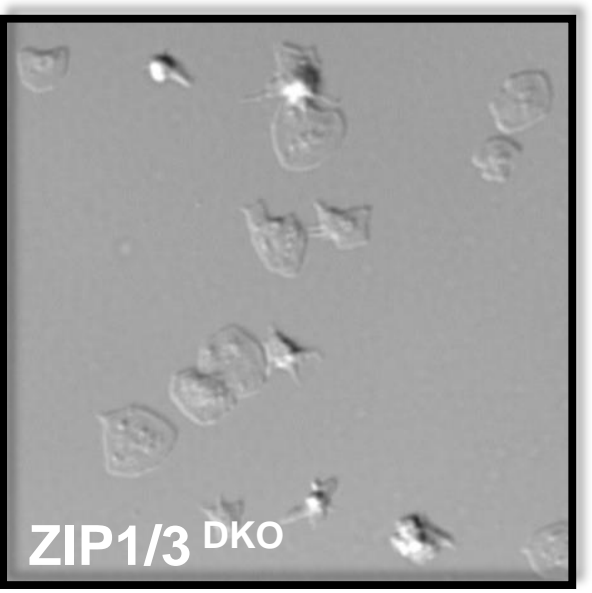

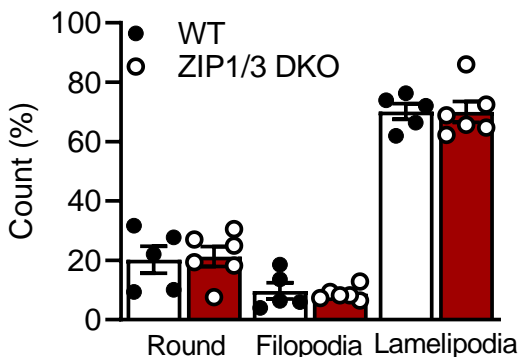


Figure 5 (Elgheznawy et al.)

A

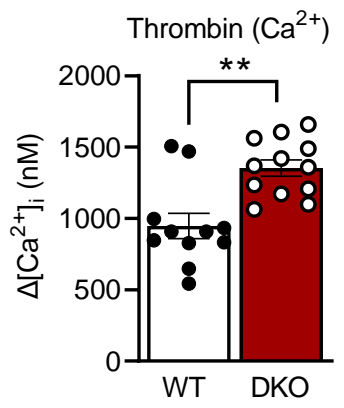

B

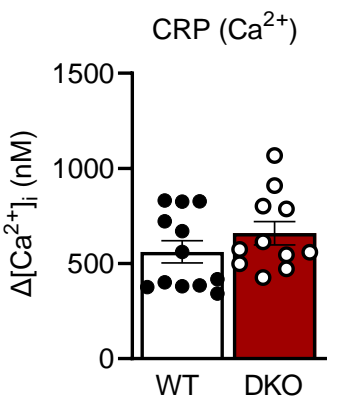


Figure 6 (Elgheznawy et al.)
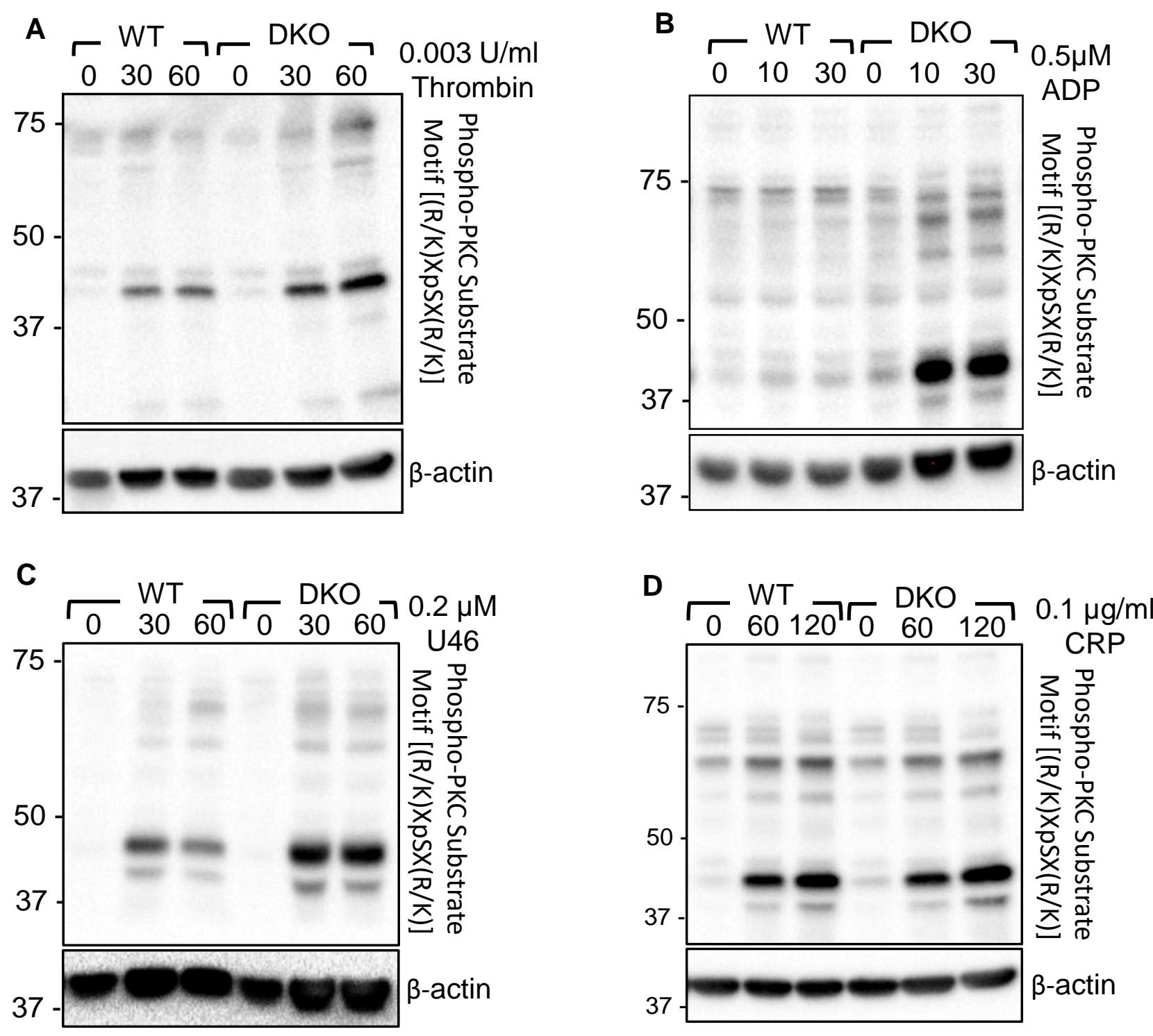

E

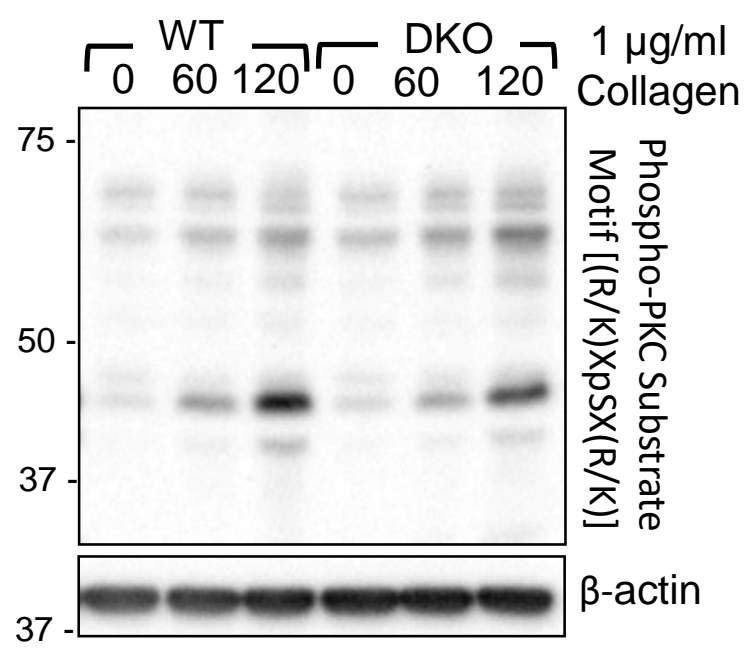


Figure 7 (Elgheznawy et al.)

A
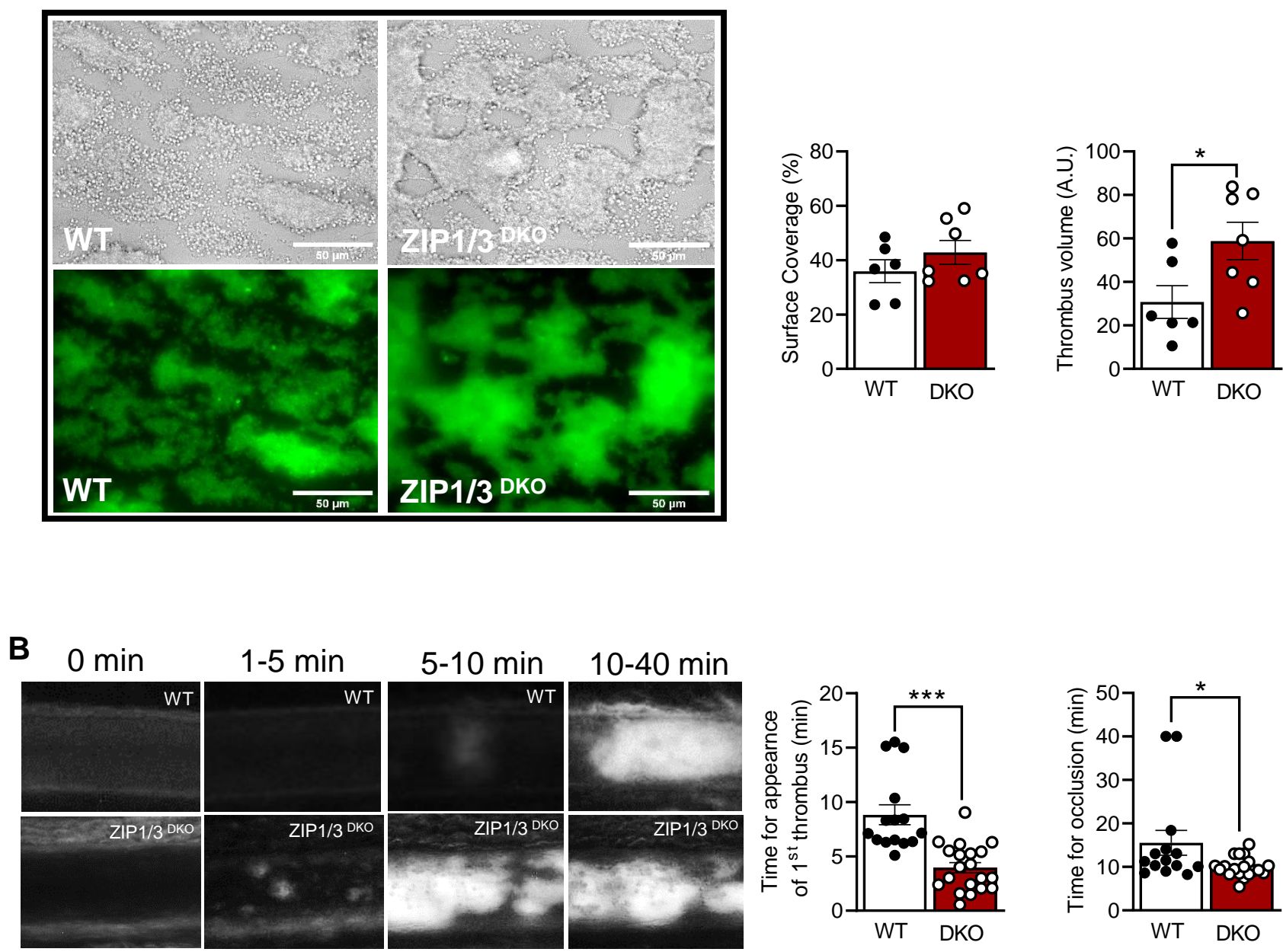